\title{
Expression of Reg gene in the Syrian golden hamster pancreatic islet regeneration model
}

\author{
R. Rafaeloff ${ }^{1}$, S. W. Barlow ${ }^{1}$, L. Rosenberg ${ }^{2}$, A. I. Vinik ${ }^{1}$ \\ 1 The Diabetes Institutes, Department of Internal Medicine, Eastern Virginia Medical School, Norfolk, Virginia, USA \\ ${ }^{2}$ Department of Surgery, McGill University, Montreal, Quebec, Canada
}

\begin{abstract}
Summary We have reported previously that cellophane wrapping of the hamster pancreas is a stimulus that leads to the induction of duct epithelial cell proliferation, followed by endocrine cell differentiation and new islet formation. Reg is a candidate gene that has been reported to be expressed in regenerating pancreatic islets, suggesting a role in islet growth. We examined Reg gene expression in the cellophane-wrap model by isolating total RNA from hamster pancreata at various times after wrapping. Northern blot analysis using a rat cDNA Reg probe showed no expression of $R e g$ in control non-wrapped hamster pancreas, whereas a strong signal was detected in control wrapped rat pancreas. Using reverse transcription of RNA followed by polymerase chain reaction (PCR) we amplified, isolated and sequenced a 194 base pair product which showed homology to rat Reg in both control and wrapped hamster pancreas. When the PCR product was used as a probe for
\end{abstract}

Northern blot analysis, no signal was detected in control non-wrapped pancreata. In contrast, a strong signal was detected 1 and 2 days after wrapping, which then returned to basal between 4 and 6 days after wrapping. A similar temporal pattern was observed using in situ hybridization to localize the Reg gene. One- and 2-day wrapped but not control pancreas expressed Reg in acinar cells, but not in islets. In conclusion, (a) Reg expression is low in the control hamster pancreas; (b) in the cellophane-wrap model of islet neogenesis, increased Reg mRNA is found within acinar tissue; (c) Reg gene may thus be involved as an acinar paracrine effector of duct cell proliferation in the initial step of islet neogenesis, but may also participate in the inflammatory response to traumatic stimuli. [Diabetologia (1995) 38: 906-913]

Key words Reg gene, islet neogenesis, cellophane wrap, hamster.
In 1982, we developed a model for islet regeneration without tumour formation in hamsters [1]. Cellophane wrapping of the hamster pancreas led to the in-

Received: 12 August 1994 and in final revised form: 14 February 1995

Corresponding author: Dr. R. Rafaeloff, The Diabetes Institute, Molecular Biology Laboratory, Eastern Virginia Medical School, 855 West Brambleton Avenue, Norfolk, VA 23510, USA Abbreviations: PCR, Polymerase chain reaction; RT, reverse transcription, MOPS, 3-[N-morpholino]propane-sulphonic acid; PSP, pancreatic stone protein; PTP, pancreatic thread protein; PAP, pancreatitis-associated protein; HGF/SF, hepatocyte growth factor/scatter factor; PCR, polymerase chain reaction; STZ, Streptozotocin; PBS, phosphate buffered saline; bp, base pair. duction of new islet formation within 2 weeks $[2,3]$. These new endocrine cells appear to derive from ductal epithelium elements $[4,5]$. Electron microscopic and immunocytochemical examination of the newlydeveloped islets identified cells containing insulin, glucagon and somatostatin [3] and wrapping was capable of reversing streptozotocin (STZ) induced diabetes $[4,6]$. The mechanism whereby cellophane wrapping induces cell proliferation and differentiation is unknown but may be related to induction of local growth factors.

Several studies have attempted to address the role of various factors regulating islet neogenesis. One such factor is Reg gene and its protein product; the findings however, have been controversial. Screening of a cDNA library derived from regenerating rat 
islets after partial pancreatectomy and nicotinamide administration revealed a novel single-copy gene encoding a 165 amino acid protein, which has been named Reg gene [7, 8]. Terazono et al. [9] reported the expression of Reg protein both in rat acinar cells and co-localized with insulin in the beta cells. The Reg gene was found to be identical to an exocrine pancreatic gene named pancreatic stone protein (PSP) [10], or pancreatic thread protein (PTP) [11] whose putative function is to inhibit calcium lithiasis in the exocrine pancreas [12]. Smith and colleagues, using $90 \%$ pancreatectomized rats showed increased Reg gene expression 1-3 days after pancreatectomy that correlated with growth of both exocrine and endocrine tissue [13]. However, they reported a lower increase in $R e g$ gene expression in their sham-operated rats and under other conditions that were not associated with pancreatic beta-cell growth [13]. Others have shown that isolated rat islets accumulate thymidine in parallel with increased $R$ eg gene expression in response to a variety of growth factors [14]. Recently, Reg protein was shown to stimulate pancreatic beta-cell growth [15] and Otonkoski et al. [16] demonstrated increased Reg expression in hepatocyte growth factor/scatter factor (HGF/SF) induced proliferation of beta cells [16]. As a corollary, Miyaura and colleagues showed that implantation of an insulinoma into New England Deaconess Hospital (NEDH) rats caused a sharp reduction in Reg expression associated with a profound reduction in non-tumour islet size relative to normal controls. Removal of the tumour resulted in rapid beta-cell proliferation and a large but transient increase in Reg mRNA levels in non-islet tissue [18]. Based upon these observations it was suggested that Reg may be expressed in acinar tissue and not in regenerating islets, but nonetheless may have been implicated in the regenerative process.

Confounding the problem of interpreting the findings with $R e g$ is the recent information that there are several Reg-related genes and proteins with structural homology. Reg II was described in the mouse pancreas and hyperplastic islets [19], pancreatitis-associated protein (PAP) I, II and III were described in the rat and human during acute pancreatitis [2023], and a novel gene named HIP was described in liver cancer [24].

In light of the possible role of Reg in islet neogenesis we elected to study the Reg gene expression in our model of islet regeneration. These studies show, in our hamster model of regeneration, that Reg gene expression precedes the islet regenerative response and occurs as shown by in situ hybridization in peri-islet acinar tissue compatible with a paracrine role of $R e g$ protein. These studies extend the scope of our understanding of the role of Reg gene as a local regulator of islet regeneration to another species and identify a possible role for $R e g$ gene in new islet formation in the adult pancreas. We also provide clear delineation between hamster Reg and PAP.

\section{Materials and methods}

Animals. Thirty outbred female Syrian golden hamsters, 7 weeks of age (Charles River, Kingston, New York, USA) were used. All the experiments were conducted in accordance with the principles and procedures outlined in the NIH "Guide for the Care and Use of Laboratory Animals". Our model for surgical induction of cell proliferation in the pancreas of the Syrian golden hamster has been described previously $[1,2]$. Briefly, a midline laparotomy incision is made. With the aid of a stereo dissecting microscope, the distal common bile duct and head of the pancreas are exposed. Using blunt dissection, an avascular plane is developed to allow the placement of a 2-mm wide strip of sterile cellophane tape (Imperial Tobacco, Montreal, Canada), which is wrapped around the head of the gland and tied loosely in position.

To study Reg gene expression in our model required measurement of total changes in Reg mRNA using Northern analysis with a cDNA probe and in situ hybridization using an RNA probe. However, since preliminary studies had indicated the uniqueness of hamster Reg, this required synthesis of our own probe.

Northern blot hybridization analysis. For Northern analysis, total cellular RNA was isolated from the hamster pancreas using the Chamczynski and Sacchi, guanidine isothiocyanate method [25], which is specifically formulated for tissues with high RNase contents.

Denatured total RNA $(30 \mu \mathrm{g})$ was separated on a $1.2 \%$ agarose, $0.6 \%$ formaldehyde/MOPS denaturing gel [26], transferred to nylon membrane (Nytran, Schleicher \& Schuell, Keene, N.H., USA) by capillary method, and immobilized by baking at $80^{\circ} \mathrm{C}$ for $1 \mathrm{~h}$. The cDNA probes used in Northern hybridizations were labelled by incorporation of $\left[\alpha^{32} \mathbf{P}\right]$-dCTP (Dupont-New England Nuclear, Boston, Mass., USA) using random primed synthesis [27] to a specific activity of greater than $1 \times 10^{9} \mathrm{cpm} / \mu \mathrm{g}$. The 194 base pair (bp) hamster pancreas polymerase chain reaction (PCR) generated probe homologous to Reg gene was synthesized in our laboratory. A 726 bp rat cDNA probe for $R e g$ was kindly provided by Dr. H. Okamoto, Toyama, Japan, chicken $\beta$-actin was purchased from Oncor Inc. (Gaithersburg, Md., USA). A $\left[\gamma^{32} \mathrm{P}\right]$-ATP (Dupont-New England Nuclear) 5'end-labelled 24mer synthetic oligonucleotide for the 18S ribosomal mRNA was used as a loading control. Prehybridization and hybridization buffers consisted of $50 \%$ formamide, $5 \times \mathrm{XSPE}, 1 \% \mathrm{SDS}$, $5 \mathrm{X}$ Denhardt's, and $200 \mu \mathrm{g} / \mathrm{ml}$ denatured salmon sperm DNA. Prehybridizations were performed at $50^{\circ} \mathrm{C}$ for $4 \mathrm{~h}$ and hybridizations at $50^{\circ} \mathrm{C}$ for $16-18 \mathrm{~h}$ with $1-5 \times 10^{6} \mathrm{cpm} / \mathrm{ml}$ of the appropriate radiolabelled probe. Washes were performed twice for $15 \mathrm{~min}$ each in $6 \mathrm{X} \mathrm{SSPE} 0.1 \% \mathrm{SDS}$ at $25^{\circ} \mathrm{C}$; $1 \times \operatorname{SSPE} 0.1 \%$ SDS at $37^{\circ} \mathrm{C}$; and under stringent conditions in $0.1 \mathrm{XSSPE} 0.1 \% \mathrm{SDS}$ at $65^{\circ} \mathrm{C}$. Autoradiography was performed at $-80^{\circ} \mathrm{C}$ for $1 \mathrm{~h}$ or 8 days by exposing scientific imaging film (X-OMAT/AR, Kodak, Rochester, N. Y., USA).

Preparation and amplification of hamster $c D N A P C R$. In order to synthesize a hamster-specific probe we applied PCR using rat-specific primers since the hamster Reg gene has not yet been isolated. The primers were selected in a region of high homology between species, anticipating that under our experimental conditions the primers would recognize the hamster 
Table 1. Primer pair for amplifying hamster Reg cDNA

\begin{tabular}{lll}
\hline cDNA & Primers & $\begin{array}{l}\text { Size of } \\
\text { PCR product } \\
\text { (base pair) }\end{array}$ \\
\hline Reg & 5'CAGATCTTTTTTGCCA- & 194 \\
& GAACATGA-3' (176-199) & \\
& 5'-CCAGGATTTGTAGAGAAA- & \\
& CAGAG-3' (346-369) & \\
\hline
\end{tabular}

gene. In addition, the primers were selected in a region of divergence between Reg and PAP genes to assure that no crosshybridization would occur during the Northern blot analysis.

cDNA was synthesized from $1 \mu \mathrm{g}$ total RNA using $50 \mathrm{U}$ Moloney murine leukemia virus (M-MLV) reverse transcriptase, primed with $100 \mathrm{ng}$ random hexamers, in a $20-\mu \mathrm{l}$ solution of $10 \mathrm{mmol} / \mathrm{l}$ Tris- $\mathrm{HCl}$ (pH8.3), $50 \mathrm{mmol} / \mathrm{l} \mathrm{KCl}, 5 \mathrm{mmol} /$ $1 \mathrm{MgCl}_{2}, 20 \mathrm{U}$ RNase inhibitor and $0.5 \mathrm{mmol} / \mathrm{l}$ each deoxynucleoside triphosphate (dNTP), for $1 \mathrm{~h}$ at $42^{\circ} \mathrm{C}$, followed by $5 \mathrm{~min}$ at $95^{\circ} \mathrm{C}$ to inactivate the RT. The resulting cDNA was amplified using PCR [28] with $0.15 \mathrm{mmol} / 1$ primers specific for the Reg gene (Table 1 ) in $100 \mu 1$ of a solution containing $50 \mathrm{mmol} / 1 \mathrm{KCl}, 10 \mathrm{mmol} / 1$ Tris-HCl (pH 8.3), $1 \mathrm{mmol} / 1 \mathrm{MgCl}_{2}$ and 2.5 units of AmpliTaq DNA polymerase. After an initial denaturation at $94^{\circ} \mathrm{C}$ for $1 \mathrm{~min}$, the samples were subjected to 40 cycles of amplification at an annealing temperature of $55^{\circ} \mathrm{C}$ for $1 \mathrm{~min}$ and extension at $72^{\circ} \mathrm{C}$ for $1 \mathrm{~min}$. To exclude any amplification product derived from genomic DNA that could contaminate the RNA preparation, we selected primers so that the amplified regions spanned an intron of the gene. The reactions were carried out in a DNA thermal cycler (Perkin Elmer Cetus, Norwalk, Conn., USA). The PCR products were analysed by electrophoresis on a non-denaturing $5 \%$ polyacrylamide gel and silver staining applying a modification of the method used by Budowle et al. [29]. To confirm their identity, the PCR product was cloned into the PCR-II vector using the TA cloning kit from Invitrogen (San Diego, Calif., USA) and sequenced with SP6 and T7 promoter primers using the TaqTrack DNA Sequencing System (Promega, Madison, Wis., USA).

Slot blot analysis. To ensure that the hamster Reg probe did not detect PAP mRNA in the Northern blots, PAP cDNA (cloned in our laboratory, unpublished data), and hamster Reg cDNA were applied to a nylon membrane in various amounts $(0.1-$ $10 \mu \mathrm{g})$ using a Minifold II (Schleicher \& Schuell) slot blotter apparatus and immobilized by baking at $80^{\circ} \mathrm{C}$ for $1 \mathrm{~h}$. The membrane was then hybridized with an $\alpha^{32} \mathrm{P}$-labelled hamster Reg probe for $24 \mathrm{~h}$ and washed under the same conditions used for the Northern analysis.

In situ hybridization. To determine the localization of Reg gene in the hamster pancreas we applied the in situ hybridization technique and used RNA probes instead of cDNA. The reason was that RNA forms stronger hybrids with the mRNA than the cDNA probes, thus allowing us to perform the hybridizations and washes under high stringency conditions.

Synthesis of RNA probe. In order to generate sense, antisense and RNA probes of high specific activity, transcription was performed in $40 \mathrm{mmol} / 1$ Tris- $\mathrm{HCl}(\mathrm{pH} 7.5), 6 \mathrm{mmol} / 1 \mathrm{MgCl}$, $2 \mathrm{mmol} / 1 \mathrm{spermidine,} 10 \mathrm{mmol} / 1 \mathrm{NaCl}, 10 \mathrm{mmol} / 1$ dithiothreitol, $0.5 \mathrm{mmol} / \mathrm{l}$ ATP, GTP, and UTP, 5 units of RNasin ribonuclease inhibitor (Promega), $80 \mu \mathrm{Ci}\left[{ }^{35} \mathrm{~S}\right]$-CTP $(850 \mathrm{Ci} / \mathrm{mmol}$, Amersham, Arlington Heights, Ill., USA), $1 \mu \mathrm{g}$ of linearized 194 bp cDNA encoding hamster Reg in PCR-II vector as tem- plate, and 5 units of T7 or SP6 RNA polymerase. Transcription was carried out at $42^{\circ} \mathrm{C}$ for $1 \mathrm{~h}$ and the DNA template was removed by incubation with 1 unit of DNase for $15 \mathrm{~min}$ at $37^{\circ} \mathrm{C}$. Radionucleotide incorporation was measured by thinlayer chromatography, yielding typical values in the range of $75-95 \%$ incorporation. This produced 80 to $120 \mathrm{ng}$ of probe with a specific activity greater than $1 \times 10^{9} \mathrm{dpm} / \mu \mathrm{g}$. After removal of unincorporated nucleotides, probes were reduced in size by limited alkaline hydrolysis to a size range of about 75$150 \mathrm{bp} \mathrm{[30]} \mathrm{and} \mathrm{stored} \mathrm{in} \mathrm{a} 50 \%$ formamide and $10 \mathrm{mmol} / \mathrm{l} \mathrm{di}$ thiothreitol solution at $-70^{\circ} \mathrm{C}$.

Hybridization. In situ hybridization was performed according to the protocol of Ingham and co-workers [31] with some modifications. Control and wrapped animals were perfused with $4 \%$ paraformaldehyde in phosphate buffered saline (PBS) at $37^{\circ} \mathrm{C}$. The pancreata were dissected out, post-fixed for $1-2 \mathrm{~h}$ in the same fixative at $4{ }^{\circ} \mathrm{C}$, cryoprotected in $30 \%$ sucrose in PBS overnight, and mounted in Tissue-Tek (Miles Inc. Elkhart, Ind., USA) at $-20^{\circ} \mathrm{C}$ for frozen sectioning. Sections (8$10 \mu \mathrm{m}$ ) were cut on a cryostat at $-20^{\circ} \mathrm{C}$. Pre-hybridization consisted of the following: Sections were fixed in $4 \%$ paraformaldehyde at room temperature, rinsed in PBS, followed by incubation in $2 \times \mathrm{XSC}(300 \mathrm{mmol} / \mathrm{l} \mathrm{NaCl}, 30 \mathrm{mmol} / 1$ sodium citrate, $\mathrm{pH} 7.0$ ) at $70^{\circ} \mathrm{C}$ for $30 \mathrm{~min}$. Sections were then treated. with $10 \mu \mathrm{g} / \mathrm{ml}$ proteinase $\mathrm{K}$ in $100 \mathrm{mmol} / \mathrm{l}$ Tris (pH 8.0) and $50 \mathrm{mmol} / 1 \mathrm{EDTA}$ for $10 \mathrm{~min}$ at $37^{\circ} \mathrm{C}$, post-fixed in $4 \%$ paraformaldehyde and rinsed in PBS. To block positive charges, sections were rinsed in $100 \mathrm{mmol} / 1$ triethanolamine $\mathrm{pH}$ 8.0 for $3 \mathrm{~min}$, acetylated in the same buffer for $10 \mathrm{~min}$, and dehydrated. Hybridization conditions were performed as described [31], and $5 \times 10^{7} \mathrm{cpm}$ of probe in $70 \mu \mathrm{l}$ of hybridization buffer was applied to the slide. The slides were then incubated for $18 \mathrm{~h}$ at $55^{\circ} \mathrm{C}$. Post-hybridization included washing slides in WDTT buffer ( $50 \%$ formamide, $300 \mathrm{mmol} / 1 \mathrm{NaCl}, 10 \mathrm{mmol} / \mathrm{l}$ Tris-HCl, $10 \mathrm{mmol} / \mathrm{l} \mathrm{NaPO} 4[\mathrm{pH} 6.8], 5 \mathrm{mmol} / 1$ EDTA, $1 \mathrm{X}$ Denhardt's solution, $10 \mathrm{mmol} / 1$ dithiothreitol) at $50^{\circ} \mathrm{C}$ and treating with RNase A $(20 \mathrm{mg} / \mathrm{ml})$ in NTE buffer $(500 \mathrm{mmol} / 1$ $\mathrm{NaCl}, 10 \mathrm{mmol} / 1$ Tris-HCl [pH 8.0], and $1 \mathrm{mmol} / 1 \mathrm{EDTA})$ at $37^{\circ} \mathrm{C}$, followed by three NTE washes and an $18 \mathrm{~h}$ incubation in WDTT at $50^{\circ} \mathrm{C}$. Slides were then dehydrated, dipped in $\mathrm{Ko}-$ dak NTB2 emulsion, dried, and stored at $4^{\circ} \mathrm{C}$. Following $1-$ 3 weeks of exposure, the slides were developed with Kodak $\mathrm{D}-19$ developer (1:1) dilution for $4 \mathrm{~min}$ at $15^{\circ} \mathrm{C}$ and fixed in Kodak fixer and stained with haematoxylin and eosin. Photographs were taken under darkfield and brightfield optics.

\section{Results}

Northern blot analysis of Reg gene expression in pancreatic tissue from rat and hamster. When pancreatic tissue was excised from control rats and from hamsters at various times after the cellophane wrapping and total RNA was isolated, an abundance of a 900nucleotide transcript was found in normal rat pancreatic tissue which hybridized to the rat Reg probe, but none was detected in hamster pancreatic tissue at 4 , 8 and 14 days after the wrapping procedure (Fig. 1). No signal was detected in a hamster insulinoma cell line (HIT cells) either. Despite performing numerous Northern hybridizations under various levels of stringency the only signal we observed with the rat Reg probe in the hamster tissue was very low. 

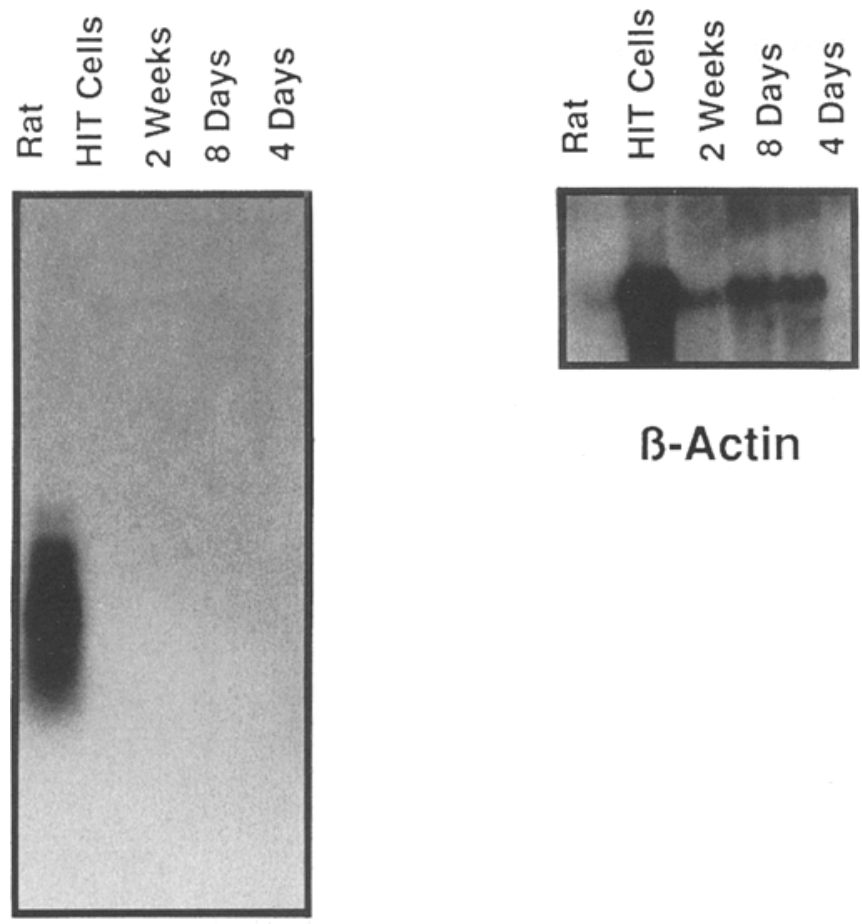

B-Actin

\section{REG Probe}

Fig. 1. Northern blot analysis of Reg gene expression in pancreatic tissue from cellophane-wrapped hamster, control rat and HIT (hamster insulinoma tumour) cells. Total RNA $(30 \mu \mathrm{g})$ was separated by electrophoresis on a $1.2 \%$ agarose, $0.6 \%$ formaldehyde/MOPS denaturing gel, and transferred to nylon membrane. Hybridization with rat Reg and $\beta$-actin cDNA probes were carried out as described in "Materials and methods". Blots were washed and exposed to film (Kodak XOmat AR) for $48 \mathrm{~h}$ at $-80^{\circ} \mathrm{C}$

The near-absence of hybridization of the rat cDNA to hamster RNA raised three main questions: (a) was the Reg gene in the hamster present only in minute amounts? (b) was the hamster mRNA sequence so different from that in the rat that it avoided detection using the rat cDNA probe? or (c) was Reg gene expressed only at specific time points which we did not include initially and thus escaped our detection? To address these questions we: (a) resorted to signal amplification using RT-PCR, (b) isolated, cloned into PCR-II vector and sequenced the PCR product, (c) used the cloned PCR fragment as a hamster-specific probe for Northern blot analysis, (d) extended the time course of wrapping to include early and intermediate time points.

Reg $m R N A$ amplification by PCR. Because it is important to be in the exponential phase of the PCR in order to relatively quantitate the PCR products, we first examined the effect of varying the number of cycles of amplification on the yield of the products corresponding to Reg. For Reg mRNA, the exponential portion of the curve corresponded to 35-45 cycles. Using Reg-specific primers we amplified and iso- lated a 194 bp product. To exclude any amplification product derived from genomic DNA that could contaminate the RNA preparation, we selected primers such that the amplified regions spanned an intron of the gene (Fig. 2 a). The product was sequenced and identified as a fragment of Reg gene with a 20-nucleotide difference compared to the rat Reg gene sequence (Fig. 2 b). The PCR product was detected in all the samples tested. Figure $2 \mathrm{c}$ shows the PCR product in control, 1- and 2-day wrapped pancreata.

Northern blot analysis of Reg gene expression in pancreatic tissue from hamster using a hamster-specific probe. To exclude the possibility that failure to detect the Reg transcript in the hamster pancreas was due to the inability of the rat probe to detect it, we used the $194 \mathrm{bp}$ PCR product as a hamster specific probe on Northern blot analysis. In addition, in order to determine whether transient expression of Reg gene in the hamster pancreas was the cause of our earlier failure to detect it in the previous experiment, we extended the time course of wrapping to include the following $1,2,6,10,28$ and 42 days. No message was detected in control hamster pancreata. However, a strong 900 bp signal was detected 1 and 2 days after wrapping which decreased thereafter (Fig.3). The size of the transcript was the same as that detected by the rat $R e g$ cDNA probe. However, the membrane hybridized with the rat Reg cDNA had to be exposed to imaging film for 8 days in order to detect any signal as opposed to 3-h exposure with the hamster probe, in spite of equal specific activity of both probes (not shown). To ensure equal loading of the samples we stripped the blot and used an $18 \mathrm{~S}$ ribosomal RNA 24mer oligonucleotide probe which hybridized equally to all samples (Fig.3).

Slot blot analysis of hamster PAP and Reg cDNAs showed clearly that the hamster Reg probe does not detect PAP (not shown). Hence, it is unlikely that the hamster Reg probe detected PAP mRNA in our Northern blot analysis data.

Localization of Reg $m R N A$ by in situ hybridization. When in situ hybridization was performed on specimens from 1-, 2- and 10-day wrapped and control non-wrapped pancreata, in the control animals we observed no expression of Reg mRNA in pancreatic ductal and acinar cells nor did we find any hybridization in the pancreatic islets (Fig. 4A, B). In contrast, tissue sections from 1-day wrapped pancreata showed strong hybridization with Reg mRNA in acinar cells (Fig. 5A, B), in particular in the vicinity of a duct (Fig. 5C). No hybridization, however, was detected in the pancreatic islets (Fig. 5A, B). Tissue sections from 2-day wrapped pancreata showed the same pattern as those from 1 day. The corresponding tissues hybridized with a sense probe showed negligible hybridization (not shown). Sections from 10-day 
910

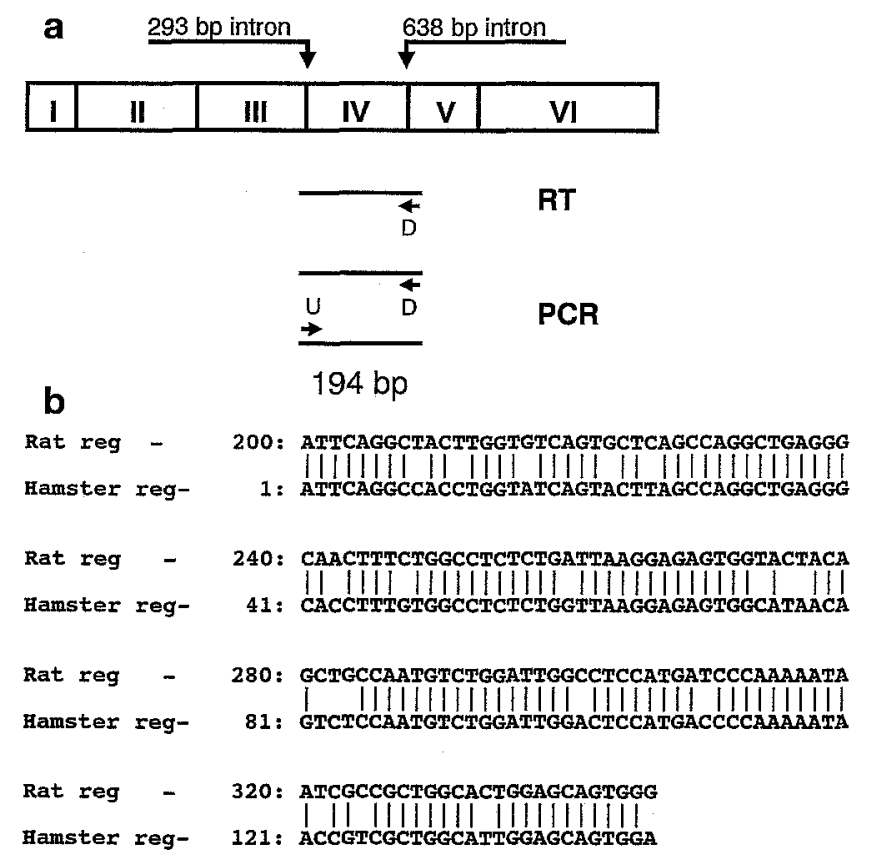

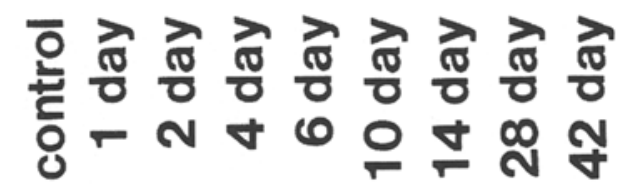

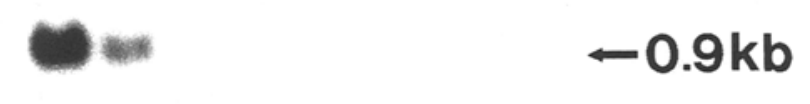

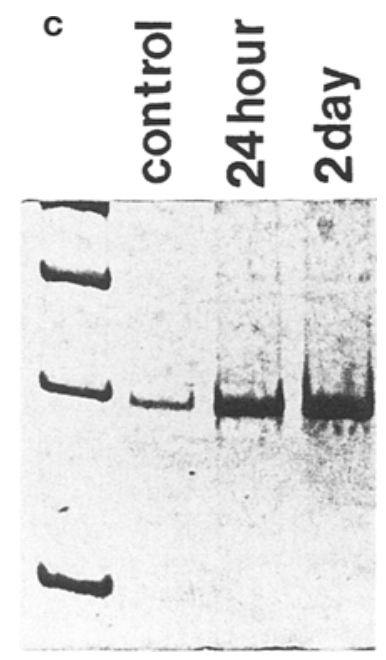

Fig. 2. a Schematic structure of Reg mRNA and RT-PCR strategy. The coding domains of Reg mRNA in the mammalian genome are indicated as I-VI and the positions of two introns in the III and in the IV domains (based on the rat sequence published by Miyashita et al. in the EMBL data base) are also indicated. The upstream (U) and downstream (D) primers (Table 1) were selected such that the amplified region spans two introns of the gene to exclude any amplification product derived from genomic DNA which could contaminate the RNA preparation. $\mathbf{b}$ Nucleic acid sequence comparison between the hamster PCR product and rat Reg gene. RT-PCR was performed using $1 \mu \mathrm{g}$ of total RNA under conditions described in "Methods", using Reg-specific primers. The amplified 194 bp product was cloned into the PCR-II vector and sequenced with SP6 and T7 promoter primers as described in "Methods". The PCR product was compared to the rat Reg sequence published by Terazono et al. [9]. A difference of 20 nucleotide was detected between the hamster and the rat Reg genes in the area examined. c Silver stained polyacrylamide gel showing Reg gene expression in whole pancreas in control nonwrapped animals and after 1 and 2 days of wrapping. Aliquots of the amplified products were fractionated on a $5 \%$ polyacrylamide gel and silver stained

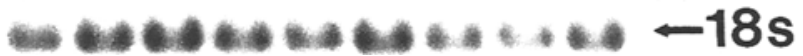

Fig. 3. Northern blot analysis of Reg gene expression in pancreatic tissue from control and wrapped hamster pancreas. $30 \mu \mathrm{g}$ of heat denatured total RNA was separated by electrophoresis on a $1.2 \%$ agarose, $0.6 \%$ formaldehyde/MOPS denaturing gel, and transferred to nylon membrane. Hybridizations with a hamster-specific cDNA probe generated by PCR and with an 18 s ribosomal 24 mer synthetic oligonucleotide probe were carried out as described in "Materials and methods." Blots were washed and exposed to film (Kodak X-Omat AR) for $3 \mathrm{~h}$ at $-80^{\circ} \mathrm{C}$

wrapped pancreata showed no hybridization with $R e g$ riboprobe (data not shown), the same as in control pancreata.

\section{Discussion}

In the current study, we examined Reg gene expression in a model wherein surgical wrapping of the head of the pancreas with cellophane in the Syrian golden hamster, results in the induction of growth, proliferation of a proto-undifferentiated cell, and differentiation of new pancreatic islet tissue from ductal cells [1-3]. The new islets form randomly in a nonuniform manner that is identical to the dynamics underlying normal islet formation during embryogenesis [4]. Over the ensuing 6 weeks, the small areas of neoislet formation enlarge and assume a size commensurate with the animal's age $[2,32]$. It was our expectation that if $R e g$ was important in islet regeneration in the adult hamster pancreas, it would have been expressed early in the regenerative response, 


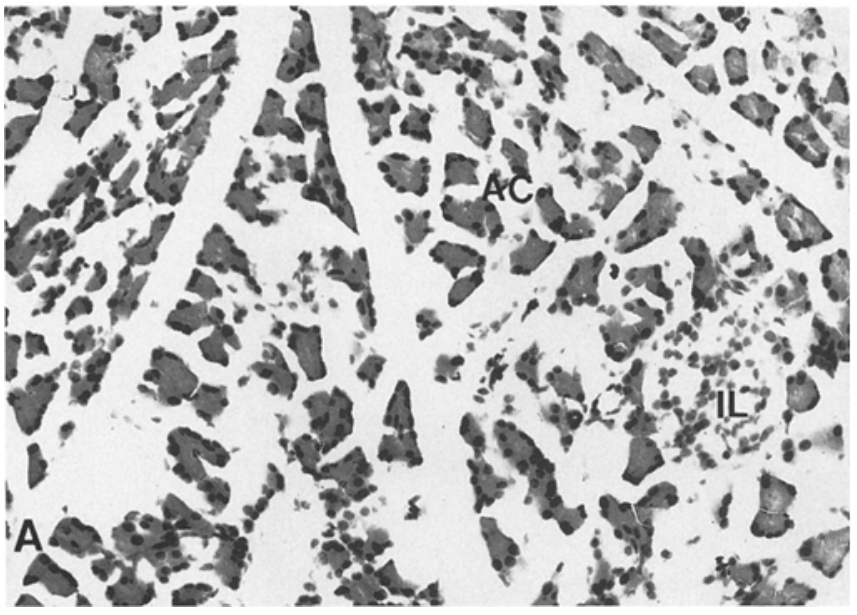

Fig. 4A, B. Localization of Reg mRNA by in situ hybridization in control pancreas. Cryostat sections from control pancreas (A, B) were hybridized with ${ }^{35}$ S-labelled antisense single stranded Reg RNA probe transcribed from a 194 bp hamster cDNA. A, B. Bright and dark-field photographs of pancreatic acinar cells (AC) and an islet (IL) showing no expression of Reg mRNA

but we were surprised to find no expression using a rat cDNA probe. Failure to detect Reg mRNA by Northern hybridization using rat cDNA was due to species differences and heterology between the rat probe and the hamster gene. The technique was clearly adequate since we found high levels of Reg mRNA in the normal rat pancreas, which was in agreement with findings reported by Miyaura et al. [17]. The differences in the sequence are not large since sequencing the $194 \mathrm{bp}$ product revealed a $13.7 \%$ difference between the hamster and the rat in the $146 \mathrm{bp}$ studied (the $194 \mathrm{bp}$ PCR product includes both primers used for amplification). Using the PCR product as a probe in Northern blot analysis showed an undetectable basal level in control animals followed by an immediate increase in $R e g$ gene expression within 1 to 2 days after wrapping which decreased thereafter and returned to control level after 4 days.

Using in situ hybridization, we observed that all of the Reg mRNA was localized in acinar tissue without expression in the islets. In control non-wrapped pancreata, no $R e g$ mRNA was detected in any area analysed. Terazono et al.[8] reported increased expression of Reg mRNA in two models of islet regeneration, $90 \%$ pancreatectomized, aurothioglucose-injected mice [7] and nicotinamide-treated rats. The Reg mRNA was shown to be markedly elevated in islets induced to proliferate by these procedures $[7,8]$. In a different model, Miyaura et al. [17] demonstrated that insulinoma implantation in NEDH rats caused a sharp reduction in the normally high expression of Reg gene in the exocrine pancreas. This reduction was associated with a profound reduction in

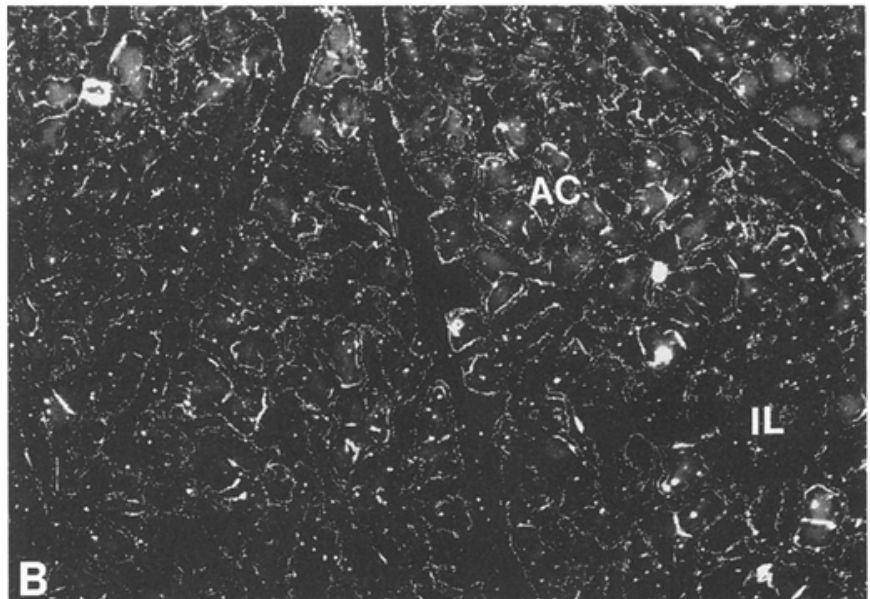

beta-cell mass. Resection of tumours resulted in a large but transient induction in Reg mRNA levels in the exocrine tissue, associated with beta-cell proliferation. Smith et al. [13] reported a rapid induction of Reg expression in the exocrine pancreatic tissue within $24 \mathrm{~h}$ after sham or partial pancreatectomy and a return to normal levels by 7 to 14 days, which did not correlate with pancreatic or beta-cell growth. Our data show that induction of islet neogenesis in the hamsters is associated with a rapid rise in Reg expression in the acinar tissue but not in islets. The findings that Reg expression occurred in exocrine tissue is compatible with its participation in islet neogenesis whether this occurred from islet [15] or from non-islet ductal tissue as we have shown [4]. The absence of Reg gene expression in the islets of the wrapped hamster pancreas is consistent with findings by investigators who report expression in exocrine but not in endocrine cell lines [18]. This does not detract from the possible role of Reg in stimulating the ductal derived pleotropic cell to differentiate into an adult islet. It does suggest however, that Reg has no role in the mature islet. This contrasts with a recent study by Bone et al. [33] who reported high levels of Reg gene in pancreatic biopsies from diabetes-prone $\mathrm{BB} /$ $S$ rats at or around the mean age for onset of diabetes (90/100 days), and suggested an association of the $R e g$ gene with an activation of islet cell adaptive repair/regeneration mechanisms in response to autoimmune islet cell attack. Other studies which support a direct effect of Reg on islets report increased Reg/ PSP expression in cultured islets after stimulation with various factors [14], stimulation of pancreatic beta-cell growth by administration of Reg protein [15] and increased Reg expression in fetal beta cells in response to HGF/SF [16]. We have previously reported that regenerating pancreatic tissue contains ilotropin, a factor which upon administration to control adult animals and to STZ-diabetic animals causes islet regeneration [34]. We postulated the presence of a local autocrine or paracrine substance capable of initiating proliferation of a proto-undifferenti- 

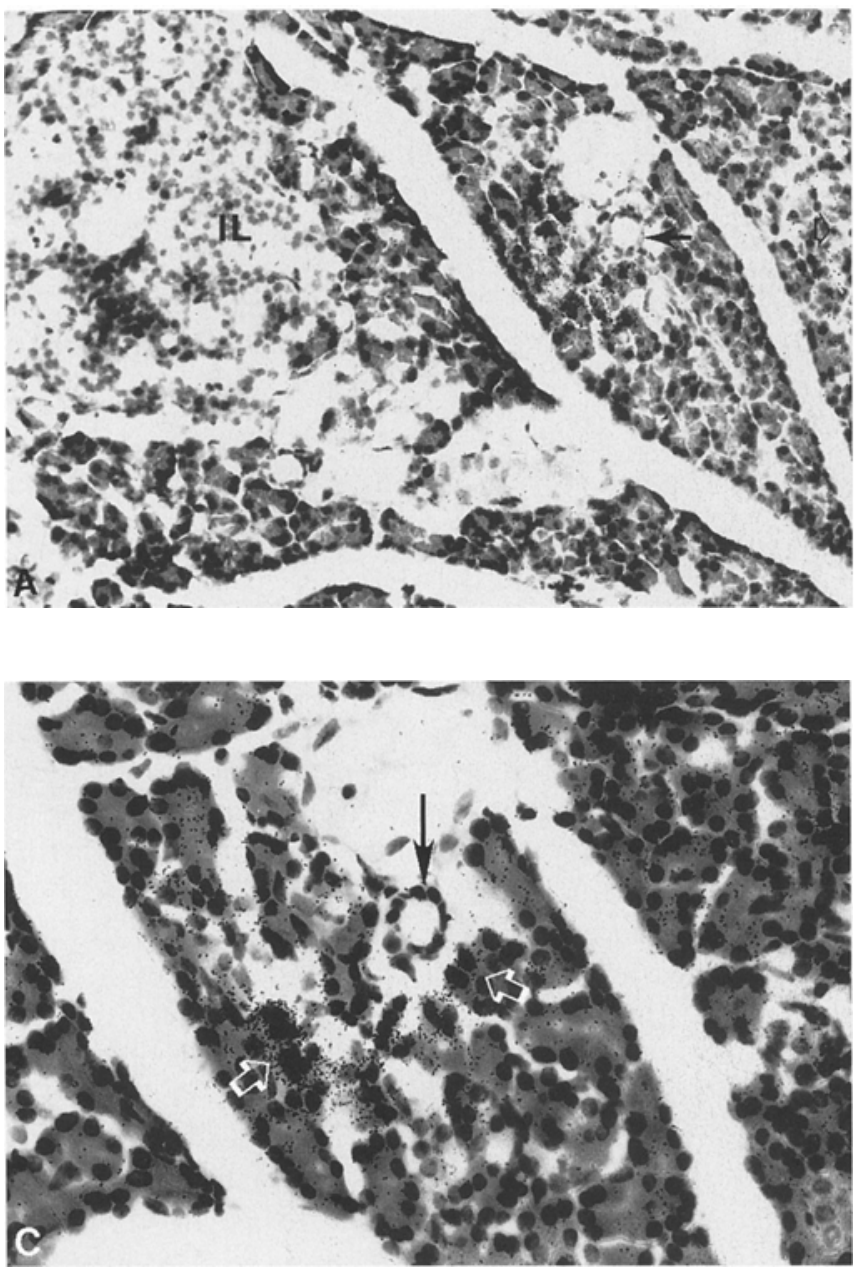

ated cell. Whether ilotropin and Reg share similarities remains to be seen.

It has been shown that the Reg protein sequence is identical to that of pancreatic stone protein (PSP) $[10,11]$ and that both are derived from the same gene [35]. The portion of the hamster Reg gene we analysed showed homology to the rat Reg/PSP gene and seems to be closer to Reg-I than Reg-II based on amino acid sequence comparison [19]. In addition, several Reg-related genes and proteins have been reported recently, defined as Reg type III by Unno et al. [19], but known as the pancreatitis-associated protein (PAP) family [20-22]. The hamster Reg probe corresponds to a bona fide Reg/PSP mRNA and not to a member of the PAP family. The insertion corresponding to amino acids TLGGE of rat PAP in position 104-109 reported by Unno et al. [19] is not present in the hamster Reg probe. In lieu of this fact and due to the high stringency conditions of hybridization and washing used in the Northern procedure we believe that it is unlikely for cross-hybridization to occur between Reg/PSP and any member of the PAP family. Moreover, we can completely exclude the possibility that the hamster Reg probe detects PAP [20-22] since slot blot analysis in which

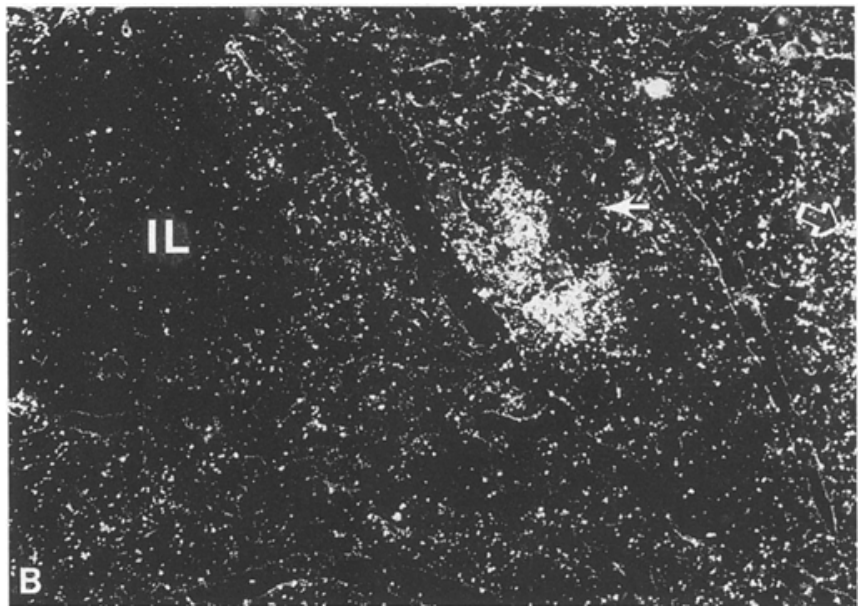

Fig.5. (A-C) Localization of Reg mRNA by in situ hybridization in 1-day wrapped pancreas. Cryostat sections from wrapped pancreas $(\mathbf{A}, \mathbf{B}, \mathbf{C})$ were hybridized with ${ }^{35} \mathrm{~S}$-labelled antisense single-stranded $\operatorname{Reg}$ RNA probe transcribed from a 194 bp hamster cDNA. A, B Bright and dark-field micrograph (magnification $=500 \times$ ) of wrapped pancreas, showing acinar cells in the vicinity of a small duct (full arrow) and in the surrounding area (empty arrow). The acinar cells express high levels of Reg mRNA. C A higher magnification $(1200 \times)$ of the micrograph shown in A. This bright-field micrograph shows the duct (dark arrow) and the acinar cells (white empty arrows), that express high levels of the Reg gene

both hamster PAP cDNA cloned in our laboratory, and hamster Reg cDNA did not hybridize with ${ }^{32} \mathrm{P}$-labelled Reg cDNA. However, we cannot completely exclude the possibility that the hamster Reg probe might detect other proteins such as HIP [22] since hamster HIP has not been cloned.

Our data thus support a possible role for Reg, or a related product in islet neogenesis from a non-islet source. The fact that Reg gene expression was only detected in acinar tissue is not supportive of a direct role of Reg in the islet per se, but there may be species differences in $R e g$ expression. It will require more studies on isolated islets from different species in non-traumatic and non-inflammatory models of neogenesis to resolve these issues.

Acknowledgements. This study was supported by a grant from The Diabetes Institutes Foundation, Norfolk, Virginia, USA

\section{References}

1. Rosenberg L, Brown RA, Duguid WP (1982) Induction of experimental nesidioblastosis: a study of islet differentiation and function. Surg Forum 33: 227-230 
2. Rosenberg L, Brown RA, Duguid WP (1983) A new approach to the induction of duct epithelium hyperplasia and nesidioblastosis by cellophane-wrapping of the hamster pancreas. J Surg Res 35: 63-72

3. Rosenberg L, Duguid WP, Vinik AI (1987) Cell proliferation in the pancreas of the Syrian golden hamster. Dig Dis Sci 32: 1185

4. Rosenberg L, Duguid WP, Rafaeloff R, Vinik AI (1994) Induction of islet cell differentiation in the hamster - further support for a ductal origin. Pancreas 9: 801

5. Rosenberg L, Vinik AI (1989) Induction of endocrine cell differentiation - a new approach to management of diabetes. J Lab Clin Med 114: 75-83

6. Rosenberg L, Duguid WP, Brown RA, Vinik AI (1988) Induction of nesidioblastosis will reverse diabetes in Syrian golden hamster. Diabetes 37: $334-341$

7. Okamoto H (1985) Molecular basis of experimental diabetes: degeneration, oncogenesis and regeneration of pancreatic beta-cells of islet of Langerhans. Bioassays 2: 15-21

8. Terazono K, Yamamoto H, Takasawa S et al. (1988) A novel gene activated in regenerating islets. J Biol Chem 263: 2111-2114

9. Terazono K, Uchiyama Y, Ide M et al. (1990) Expression of Reg protein in rat regenerating islets and its co-localization with insulin in beta cell secretory granules. Diabetologia 33: 250-252

10. Rouquier S, Giorgi D, Iovanna J, Dagorn JC (1989) Sequence similarity between the Reg transcript and pancreatic stone protein mRNA. Biochem J 264: 621-624

11. Gross J, Carlson RI, Brauer AW, Margolies MN, Warshaw AL, Wands JR (1985) Isolation and characterization of an unusual pancreatic human secretory protein. J Clin Invest 76: $2115-2126$

12. Giorgi D, Bernard JP, Rouquier S, Iovanna J, Sarles H, Dagorn JC (1989) Secretory pancreatic stone protein messenger RNA: nucleotide sequence and expression in chronic calcifying pancreatitis. J Clin Invest $84: 100-106$

13. Smith FE, Bonner-Weir S, Leahy JL et al. (1994) Pancreatic Reg/Pancreatic stone protein (PSP) gene expression does not correlate with beta-cell growth and regeneration in rats. Diabetologia 37: 994-999

14. Francis PJ, Southgate JL, Wilkin TJ, Bone AJ (1992) Expression of an islet regenerating (Reg) gene in isolated rat islets: effects of nutrient and non-nutrient growth factors. Diabetologia 35: 238-242

15. Watanabe T, Yutaka Y, Yonekura H et al. (1994) Pancreatic beta-cell replication and amelioration of surgical diabetes by Reg protein. Proc Natl Acad Sci USA 91: 35893592

16. Otonkoski T, Mally IM, Hayek A (1994) Opposite effects of beta-cell differentiation and growth on Reg expression in human fetal pancreatic cells. Diabetes 43: 1164-1166

17. Miyaura C, Ling C, Appel M et al. (1991) Expression of Reg/PSP, a pancreatic exocrine gene: relationship to changes in islet beta-cell mass. Mol Endocrinol 5: 226-234

18. Newgard CPA, Hughes S, Chen L, Okamoto H, Milburn JL (1989) The Reg gene is preferentially expressed in the exocrine pancreas during islet regeneration. Diabetes 38: 49A (Abstract)
19. Unno M, Yonekura H, Nakagawara K, Watanabe T, Miyashita SM, Okamoto H (1993) Structure, chromosome localization, and expression of mouse Reg genes, Reg I and Reg II. J Biol Chem 268: 15974-15982

20. Iovanna J, Orelle B, Keim V, Dagorn JC (1991) mRNA sequence and expression of rat pancreatitis associated protein, a lectin-related protein overexpressed during acute experimental pancreatitis. J Biol Chem 266: 24664-24669

21. Frigerio JM, Dusetti N, Keim V, Dagorn JC, Iovanna J (1993) Identification of a second PAP. mRNA cloning, gene structure, and expression during pancreatitis. Biochemistry 32: 9236-9241

22. Frigerio JM, Dusetti N, Garrido P, Dagorn JC, Iovanna J (1993) The pancreatitis associated protein III (PAP III), a new member of the PAP gene family. Biochim Biophys Acta 1216: 329-331

23. Orelle B, Keim V, Masciotra L, Dagorn JC, Iovanna J (1992) Human pancreatitis associated protein. mRNA cloning and expression in pancreatic diseases. J Clin Invest 90: 2284-2291

24. Lasserre C, Christa L, Simon MT, Vernier P, Brechot C (1992) A novel gene (HIP) activated in human primary liver cancer. Cancer Res 52: 5089-5095

25. Chamczynski P, Sacchi N (1987) Single-step method of RNA isolation by acid guanidinium thiocyanate-phenolchloroform extraction. Anal Biochem 162: 156-159

26. Maniatis T, Fritsch EF, Sambrook J (1989) Molecular cloning: a laboratory manual. Cold Spring Harbor Laboratory, Cold Spring Harbor, NY

27. Feinberg AP, Vogelstein B (1983) A technique for radiolabelling DNA restriction endonuclease fragments to high specific activity. Anal Biochem 132: 6

28. Saiki RK, Gelfand DH, Stoffel S et al. (1988) Primer-directed enzymatic amplification of DNA with thermostable DNA polymerase. Science 239: 487-491

29. Budowle B, Chakraborty R, Giusti AM, Eisenberg AJ, Allen RC (1991) Analysis of the VNTR locus DIS80 by the PCR followed by high-resolution PAGE. Am J Hum Genet $48: 137-144$

30. Cox KH, DeLeon DV, Angerer LM, Angerer RC (1984) Detection of mRNAs in sea urchin embryos by in situ hybridization using asymmetric RNA probes. Dev Biol 101: 485-502

31. Ingham PW, Howard KR, Ish-Horowicz D (1985) Transcription pattern of the drosophila segmentation gene hairy. Nature 318: 439-445

32. Rosenberg L, Dafoe DC, Turcotte JG (1987) Enhancing hamster pancreatic islet isolation by induction of nesidioblastosis. Transpl Proc 19: 907

33. Bone AJ, Zhang S, Webster KA, Banister SH (1992) Expression of the regenerating (Reg) gene in the pancreas of the prediabetic BB/S rat. Diabetes 41: $160 \mathrm{~A}$ (abstract)

34. Vinik AI, Pittenger GL, Rafaeloff R, Rosenberg L (1993) Factors controlling pancreatic islet neogenesis. Tumor Biol 14: $184-200$

35. Giorgi D, Bernard JP, DeCaro A et al. (1985) Pancreatic stone protein. I. Evidence that is encoded by a pancreatic ribonucleic acid. Gastroenterology 89: 381-386 